\title{
Shrinking Behaviour of Badland Soil Under Different Soil Covers
}

\author{
Teodoro Di Tommaso*, Stella Lovelli, Mariana Amato, Michele Perniola \\ Dipartimento di Scienze dei Sistemi Colturali, Forestali e dell'Ambiente, Università della Basilicata \\ Via dell'Ateneo Lucano 10, 85100 Potenza, Italy
}

Received: 24 March 2009. Accepted: 31 May 2009.

\begin{abstract}
Indicators used to estimate the soil structure stability facing erosion are the basis of major indicators of soil quality, and their behaviour is affected by permanent soil properties, vegetation and management. The relation between the pore-volume fraction occupied by water and the pore size distribution in clay soils is studied by the shrinkage curve describing clay soil porosity dynamics as a function of soil moisture. The aim of this work is to study the shrinking behaviour of the surface soil in a badland site through the shrinkage curve and to assess its relations with vegetation. Six treatments with different soil vegetation cover and aspect were selected on a badland site in Pisticci (Southern Italy). Shrinkage curves were built from natural aggregates collected in the 0-10 cm soil depth. Soil stability under shaking in water was also determined, with pre-treatments in water, alcohol and benzene for the determination of the SSI (Soil Stability Index). Soil organic matter, electrical conductivity, ESP were determined in order to investigate the relations between soil cover, chemical properties, SSI and shrink-swell behaviour. Vegetation was associated with lower soil salinity and ESP, and higher soil organic matter content. Vegetated sites showed a higher SSI and a lower overall swelling. The shrinkage curves for samples from vegetated areas lack of the structural phase of shrinkage, likely due to the combined effect of lower ESP and the mechanical effect of plant roots. All soil properties and indicators point to a higher stability of soils under grass in the south aspect and under shrub in the north one.
\end{abstract}

Key-words: shrinkage curves, soil structure stability, erosion, soil porosity, badlands.

\section{Introduction}

The amount and distribution of soil pores are major concerns in farm management and soil use, and they affect many soil physical properties (Boivin et al., 2005). Among the latter, there are saturated hydraulic conductivity and air permeability, which have important consequences on surface runoff and erosion (Arvidsson, 2001; Logsdon et al., 1992; Kirby, 1991; Blackwell et al., 1990). Due to their manifold effects on soil behaviour, soil pores are used to build the most used physical indicators of soil quality (Bouma, 2002). Among the several factors affecting soil porosity and its dynamics, plants play a major role. They positively affect soil structure by shedding and exuding large amounts of organic matter and exert direct mechanical effects reinforcing the soil by their root systems (Greenway, 1987), thus stabilizing soil structure.

Traditionally, only static indicators have been used to quantify the effects of vegetation on the status of the soil-pore system, either linked to the amount and distribution of pores, or to the stability of soil aggregates to wet-shaking. The most used indicator is soil compaction that is a reduction of total porosity (Alakukku, 1996; Arvidsson and Hakansson, 1996), but pore morphology (Kremer et al., 2002; Wiermann et al., 2000; Horn et al., 1994; Bullock et al., 1985) and pore size distribution (Richards et al., 2001;

\footnotetext{
* Corresponding Author: Tel.: +39 971 295385; Fax: +39 971 205378. E-mail address: tditommaso@unibas.it
} 
Alakukku, 1996; Horn et al., 1995; Gupta et al., 1989) are also of great importance.

Vegetation has been found to be associated with changes in soil properties linked to soil structure stability in badland areas (Del Prete et al., 1997) where erosion is a major phenomenon linked to the dynamics of the surface soil layer (Clarke and Rendell, 2000). This has led to the hypothesis that vegetation may be associated with areas of different shrinkage behaviour of soil or, as defined by Braudeau et al. (2004; 2005), different hydrostructural behavior of the soil surface layer.

Badlands are deeply dissected landforms of high relative relief and drainage density, considered among the areas with the highest erosion rate in the world. The interactions between soil and climate have been the object of several studies in the formation of these landforms and their rate of erosion. Different mechanisms of erosion dominate in different badland areas, but in southern Italy formation processes like rain splash are important (Rendell, 1982, 1986) and the amount of eroded soil is strongly dependent on the thickness of the weathered clay layer (Clarke and Rendell, 2005) which is washed away during one or a few events generally at the end of summer. Phillips (1998a and b) found that the most significant soil features in determining soil erodibility are the percentage of organic matter and the exchangeable sodium percentage (ESP), which affect the stability of soil aggregates to the action of water. Another mechanism of soil erosion in these landforms involves the formation of subsurface "piping" channels which then collapse (Del Prete et al., 1997; Farifteh and Soeters, 1999). Piccarreta et al. (2006) linked piping mechanisms to the dispersive nature of the material as well as topographic landscape features, and argued that the process of badland formation is more complex, since mass movement also plays an important role.

In such environments, indicators of soil stability to erosion are traditionally linked to stability of surface soil, like the stability of aggregates to shaking. This indicator has been extensively measured in agronomical works by means of the SSI (Soil Stability Index) (Henin et al., 1973) equal to the percent ratio of aggregated material to the material susceptible to aggregation after shaking soil aggregates in water on a sieve. The index has been used to assess the sustainability of different agricultural management techniques and the susceptibility of surface soil to erosion, because it was taken as a measure of inter-aggregate bond strength and of the extent to which aggregates would yield smaller and therefore easier to be transported by runoff particles under the mechanical and physicalchemical action of water (Cavazza and Linsalata, 1969). It has also been proposed as a test for geomorphology (Grieve, 1979) that has been used to describe the stability of badland soils (Robinson and Phillips, 2001; Phillips, 1998a; b).

The shrinkage behaviour of soils may be used to study the relation between the porevolume fraction occupied by water and the pore size distribution in clay soils (Boivin et al., 2005; Chertkov, 2003). The shrinkage curve describes clay soil porosity dynamics as a function of soil moisture. Its canonical form relates soil specific volume $\left(\mathrm{cm}^{3} \mathrm{~g}^{-1}\right)$ with soil water content in weigh $\left(\mathrm{g} \mathrm{g}^{-1}\right)$, following McGarry and Malafant (1987), as shown in figure 1, but more recently many authors described the theoretical shrinkage curve as the ratio between void ratio $\left(\mathrm{cm}^{3}\right.$ $\mathrm{cm}^{-3}$ ) and moisture ratio $\left(\mathrm{cm}^{3} \mathrm{~cm}^{-3}\right.$ ) (Chertkov, 2007; Cornelis et al., 2006; Boivin et al., 2005; Groenevelt and Grant, 2004), which allows a more precise checking of the obtained results. That is the reason why we have chosen to built the curves according to later authors. The curve is generally divided in three zones (Fig. 1). Starting from a full saturated sample of clay soil, the first phase of the shrinkage process is called "structural", where the shrinkage curve describes a bulk volume reduction smaller than the volume of the lost water. As the sample shrinkage proceeds, bulk volume decreases at the same rate of, or slightly smaller than (Groenevelt and Grant, 2004), the lost water volume and this phase is called "normal". The third part of the curve describes a process where, again, the lost water volume exceeds the sample volume decrease, and it is called "residual". The transition point between the normal and residual zones of the curve is called "air entry point", and it marks the air entry inside the aggregates. The other transition point, between the structural and the normal shrinkage zones of the curve, is the limit of the sample swelling because, at this point, a further and limited increase of volume, as a function of soil moisture 


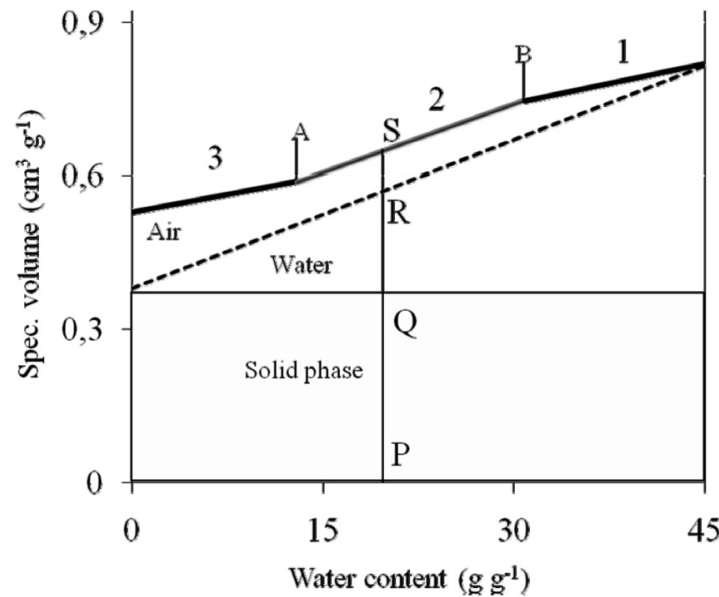

Figure 1. The theoretical shrinkage curve. The $\mathrm{Y}$ axis shows the specific volume $\left(\mathrm{cm}^{3} / \mathrm{g}^{-1}\right)$ or the void ratio $\left(\mathrm{cm}^{3} / \mathrm{cm}^{-3}\right)$ while $\mathrm{X}$ axis shows the water content $\left(\mathrm{g} / \mathrm{g}^{-1}\right)$ or the moisture ratio $\left(\mathrm{cm}^{3} \mathrm{~cm}^{-3}\right)$ of soil samples. 1, 2 and 3 are the Structural, Normal and Residual shrinkage phases, respectively. $\mathrm{A}=$ air entry point; $\mathrm{B}=$ aggregate swelling limit. The dotted line is the reference line showing the shrinkage curve of a theoretical biphasic system made up by a solid and a liquid phase where each water loss is equal to a correspondent loss of total volume. PQ and QR are the relative part of specific volume of solid and liquid phases in each point of the curve. SR is the relative part of specific volume of water phase (McGarry and Malafant, 1987, modified).

increment, is caused by water entering the inter-aggregate pores. When measurements are made at the scale of single aggregates, this latter increment is not registered because of the lack of big inter-aggregates pores. Mitchell (1992) proposed to call the central part of the shrinkage curve "basic" while Groenevelt and Grant $(2004,2001)$ preferred referring to it as "proportional", since the sample volume reduction is actually proportional to the water loss, even though the ratio is not always 1:1. In fact, according to Brandeau et al. (1999), the slope of this part of the curve is 1 only for structureless clay soils, while in well structured ones it can be much smaller than 1 and as low as 0.1 . A fourth stage of the shrinkage process is described (Bronswijk, 1991; Stirk, 1954; Haines, 1923) and called "zero shrinkage stage", where there is no volume reduction as water volume further decreases since soil particles have reached their densest configuration (Bronswijk, 1991) in the given conditions and only undergo a reorganization leading to micro-cracks formation (Bruand and Prost, 1987). Groenevelt and
Grant (2004) reported that two shrinkage processes, which the authors refer to as "primary" and "secondary", occur from the air entry point to the oven dry state, their magnitude changing according to soil composition.

Total soil porosity can be calculated from the shrinkage curve as the difference between bulk and solid phase volumes, and water loss upon drying gives the water filled porosity with the complementary porosity filled by air. The difference between water loss and bulk soil decrease volumes depends on the stability of soil structure and is described by the slopes of the different shrinkage phases.

The structural stage of the shrinkage curve only occurs in soils that develop inter-aggregate porosity. Chertkov (2007) developed a model to predict the reference soil shrinkage curve based on soil with a clay content equal to or greater than $40 \%$. He suggested to estimate the crack volume as the difference between the reference and the observed shrinkage curve, and ascribed the differences to soil texture, together with cracks and other pore distribution since silt, sand and voids of any origin disturb the continuity of clay and its shrinkage behaviour in soils (Chertkov 2003, 2007). Non-textural effects on soil shrinkage are included in the shrinkage curves of McGarry and Daniels (1987) from cultivated soils. The objective of this study was to investigate the swelling/shrinkage cycle of clay soils under different vegetation types, building shrinkage curves in badland soils to integrate information provided by SSI as an indicator of soil quality.

\section{Materials and methods}

The study was carried out at Pisticci (MT), Italy, on a badland hill in six sites selected for different vegetation cover (bare, grass, shrub) in factorial combination with aspect $(\mathrm{N}, \mathrm{S})$, thus yielding six experimental treatments:

$\mathrm{BS}=$ bare, south facing;

$\mathrm{BN}=$ bare, north facing;

GS = grass cover, south facing;

$\mathrm{GN}=$ grass cover, north facing

$\mathrm{SS}=$ shrub cover, south facing;

$\mathrm{SN}=$ shrub cover, north facing.

Vegetation of GS and GN areas was a grassland community dominated by Lygeum spartum 
L. (Brullo, et al., 1990). In SS isolated small halophyte bushes like Sueda fruticosa $L$. were common, whereas in the NS area larger bushes were found, with more continuous soil cover and relict forms of Pistacia lentiscus L.

The clay content of the area ranged from 32 and $40 \%$, with a clay mineralogy of $5 \%$ Int., 14\% Smec., 27\% Ill., 6\% Kaol., with 18\% Quarz. and 20\% Carb. (Del Prete et al., 1997).

In each site triplicate soil samples were taken from the first $5 \mathrm{~cm}$ of soil depth for the measurement of soil chemical characteristics and root density: organic matter content ( $\mathrm{K}$ dichromate method), $\mathrm{pH}$ (soil-water suspension), electrical conductivity (saturated paste), exchangeable and soluble cations. ESP (Exchangeable Sodium Percentage) was assessed as a percentage of exchangeable sodium cation on the total exchangeable cations.

Root length density ( $R L D, c m$ of roots per $\mathrm{cm}^{3}$ of soil) was determined according to Amato and Pardo (1994) after clay dispersion by a solution of sodium hexametaphosphate $(85 \%)$ and sodium bicarbonate $(15 \%)$ at $10 \% \mathrm{w} / \mathrm{w}$ dilution, and after filtering through a $0,2 \mathrm{~mm}$ square meshed sieve. Root length was measured by a line-intersection method (Newman, 1966) and converted into RLD multiplying the obtained values, expressed per unit soil dry weight, by the soil bulk density that was obtained with the cylinder method on triplicate samples (Blake and Hartge, 1986)

Ten aggregates were collected in each area and used for building the soil shrinkage curve:

clods were wrapped by two orthogonal wire loops previously weighed, leaving enough wire to hang the clod to a suspension balance. Then clods were weighed with the wires, and moisture content was determined after oven-drying at $105{ }^{\circ} \mathrm{C}$ on three aggregates per treatment. Remaining aggregates were dip in Saran* (Saran resin/methyl-ethyl-ketone $1 / 7 \mathrm{w}: \mathrm{w}$ ) for about $1 / 4$ of their surface in order to allow handling after saturation without altering their bulk volume. When resin was dry they were weighed again to account for the weight of added Saran, then saturated on pressure plates made with porous glass bed over Buchner funnels and with cotton as contact material, at 0.001 bar of pressure (Hillel, 1971), and completely coated after saturation. Saran* was used for its ability to allow water vapour losses during the shrinkage phase but to prevent water entry during aggregate immersion in water.

Some samples showed an abnormally high moisture content since the moisture ratio was higher than the void ratio. We attributed this to water trapping between the aggregate and the Saran coating during saturation, and discarded the corresponding measurements.

The coating was completed by dipping clods in the resin holding them by the wire and left hanging under hood for 15-30 min. to allow solvent to evaporate. Submerging and drying were reiterated once or more times, as necessary, till getting clod waterproofed. Covered clod and wire were again weighed in air and afterwards in water for volume determination by the Archimedes principle, recording water temperature.

Aggregates were then left to dry at $20{ }^{\circ} \mathrm{C}$ under hood. The volume and weight were determined during the course of water loss by double weighing in air and water for volume determination.

In order to correct the measurements for soil water content, we calculated sample dry weight $\mathrm{W}_{\text {ods }}(\mathrm{g})$ as follows for all samples:

$$
\mathrm{W}_{\mathrm{ods}}=\frac{\mathrm{W}_{\mathrm{sa}}}{1+\theta_{\mathrm{w}}}
$$

where:

$\theta_{\mathrm{w}}=$ water content of the sample $(\mathrm{g} / \mathrm{g})$;

$\mathrm{W}_{\mathrm{sa}}=$ net weight of soil aggregate in air $(\mathrm{g})$.

We calculated sample bulk density as follows:

$$
\rho_{\mathrm{b}}=\frac{\rho_{\mathrm{w}} \mathrm{W}_{\mathrm{ods}}}{\left[\mathrm{W}_{\mathrm{sa}}-\mathrm{W}_{\mathrm{spw}}+\mathrm{W}_{\mathrm{pa}}-\left(\mathrm{W}_{\mathrm{pa}} \rho_{\mathrm{w} /} \rho_{\mathrm{p}}\right)\right]}
$$

where:

$\rho_{\mathrm{b}} \quad=$ sample bulk density $\left(\mathrm{g} / \mathrm{cm}^{3}\right)$

$\rho_{\mathrm{w}} \quad=$ water density $\left(\mathrm{g} / \mathrm{cm}^{3}\right)$

$\mathrm{W}_{\text {ods }}=$ sample oven-dry weight $(\mathrm{g})$

$\mathrm{W}_{\mathrm{sa}}=$ clod net weight in air $(\mathrm{g})$

$\mathrm{W}_{\mathrm{spw}}=$ sample net weight plus Saran in water (g)

$\mathrm{W}_{\mathrm{pa}}=$ Saran weight in air $(\mathrm{g})$

$\rho_{\mathrm{p}}=$ Saran density $\left(\mathrm{g} / \mathrm{cm}^{3}\right)$

Resin density $\rho_{\mathrm{p}}$ was determined during drying by periodical weighing of a resin-coated glass lens, in order to account for changes due to evaporation of the solvent throughout the course of the experiment. 
Shrinkage curves were built based on clod bulk density determined as above at different moisture levels by relating void ratio and moisture ratio for each experimental treatment.

The stability of soil aggregates to shaking in water was also measured, on triplicate samples with the method of Tiulin - Meyer modified as in Cavazza and Linsalata (1969): aggregates of 1 to $2 \mathrm{~mm}$ were obtained by sieving air-dried soil samples and were shaken over a $0.2 \mathrm{~mm}$ sieve in water.

The stability index was calculated as:

$$
\mathrm{SSI}=\frac{(\mathrm{Ao}-\mathrm{Gs})}{(\mathrm{At}-\mathrm{Gs})} \times 100
$$

where:

Ao $=$ weight of materials collected on the sieve after shaking in water $(\mathrm{g})$

At $=$ total sample weight $(\mathrm{g})$

Gs $=$ gross sand fraction (soil particles larger than $0.2 \mathrm{~mm}$ diameter $)(\mathrm{g} / \mathrm{g})$.

Before shaking in water, samples were subjected to three pre-treatments as suggested by Henin et al. (1973): one with ethyl alcohol, one with benzene, one with no treatment.

Soil analysis data underwent variance analysis and means were separated with the Duncan's test. Shrinkage curve parameters were estimated by the regression with a three stage model as suggested by McGarry and Malafant (1987).

\section{Results and discussion}

Soil chemical characteristics are shown in Figures 2, 3 and 4. Values of organic matter were significantly lower in bare areas, and higher under shrubs sites, more so in the north-facing slope (Fig. 2a) where shrubs were larger and provided a more continuous soil cover. All soil chemical features also showed a statistically significant relation with plant cover and aspect: soils at the north-facing slope showed the lowest $\mathrm{pH}$ (Fig. 2b) and amount of total, exchangeable and soluble salts and sodium (Fig. $3 b$ and $4 b$ ), especially under shrubs, whereas in the south-facing soils values were not statistically different between vegetation types but they were lower than those recorded in the bare soil. The origin of salts, and namely sodium chloride, in the soil under investigation is based on
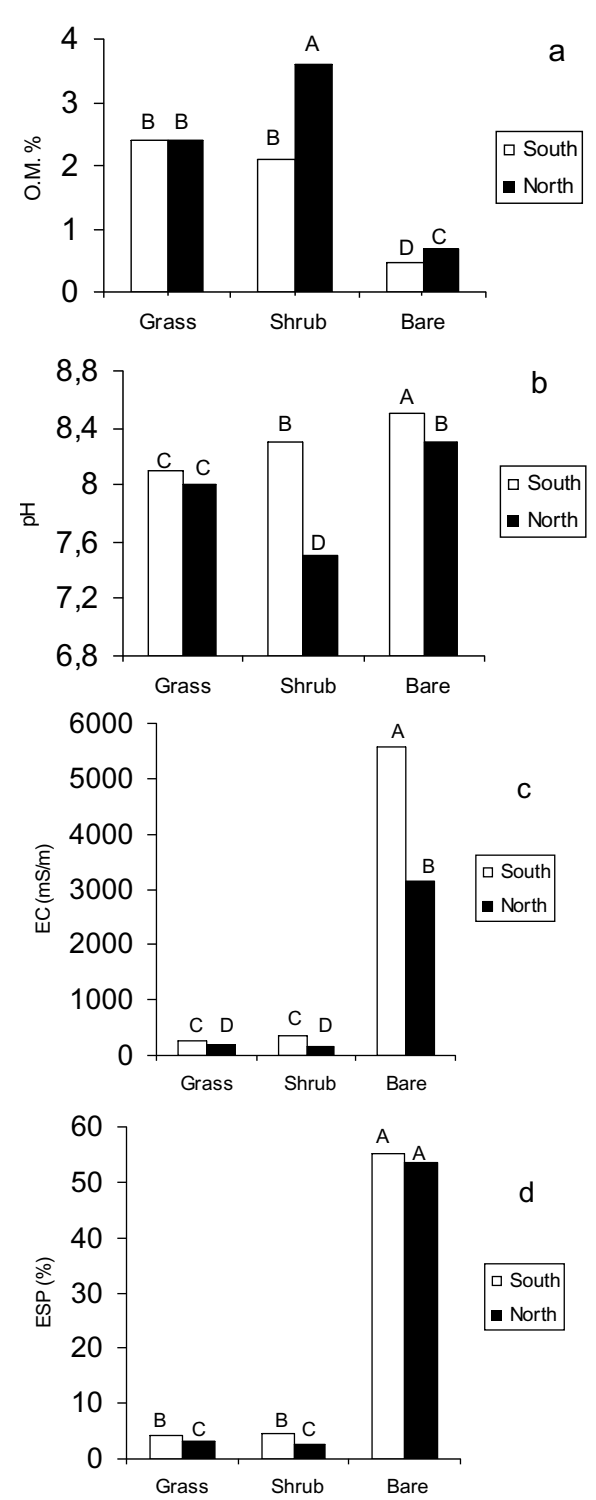

Figure 2. $\mathrm{a}=$ Organic Matter $(\%) ; \mathrm{b}=\mathrm{pH} ; \mathrm{c}=$ Electric Conductivity $(\mathrm{mS} / \mathrm{m}) ; \mathrm{d}=$ Exchangeable Sodium Percentage (\%). Different letters show significantly different values for $\mathrm{P} \leq 0,01$.

the geological history of the studied area deeply carved in the Upper Pliocene-Calcabrian SubAppennine Clay formation of the Bradanic Foredeep covered by marine sediment terraces (Piccarreta et al., 2006) (Fig. 5). Both aspect and plant cover are involved in hillslope hydrology. The salt balance of vegetated soils is affected by several features of plant cover and physiology: shading from plant canopies alters the heat-bal- 


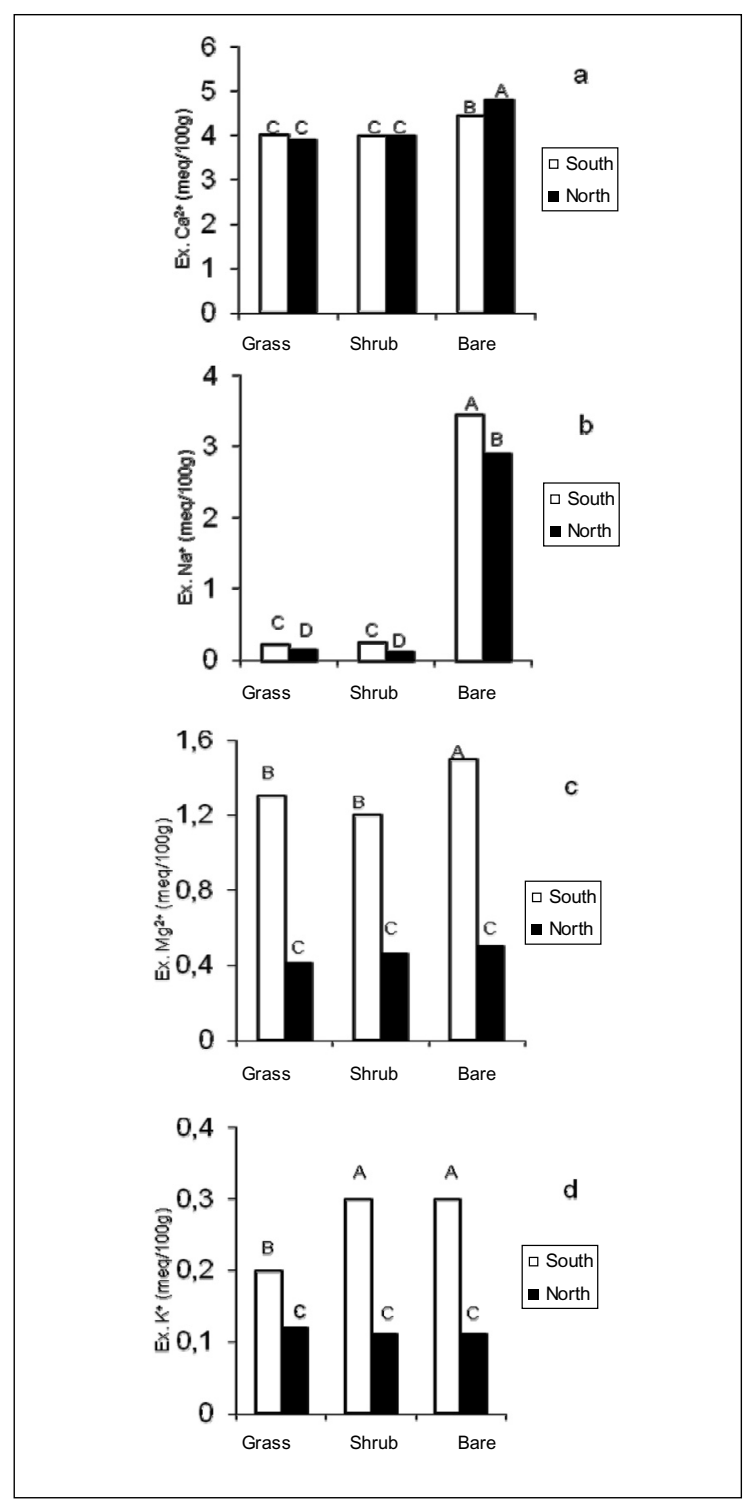

Figure 3. Exchangeable ions in soil (meq/100g): $\mathrm{a}=\mathrm{Ca}^{2+} ; \mathrm{b}$ $=\mathrm{Na}^{+} ; \mathrm{c}=\mathrm{Mg}^{2+} ; \mathrm{d}=\mathrm{K}^{+}$. Different letters show significantly different values for $\mathrm{P} \leq 0,01$.

ance (Ritchie, 1972), while evaporation/infiltration ratio is affected by plant residues and cover (Amato, 2004).

Plant ion uptake is selective but halophytic species, such as those found in our study area, are able to take up and store sodium chloride in specific organs and structures (Skaggs et al., 2006; Worrall and Pearson, 2001; Johannesson and Lyons, 2000). Such processes are compatible with the reduced content of total salts and specifically sodium in the surface soil of vegetated areas.

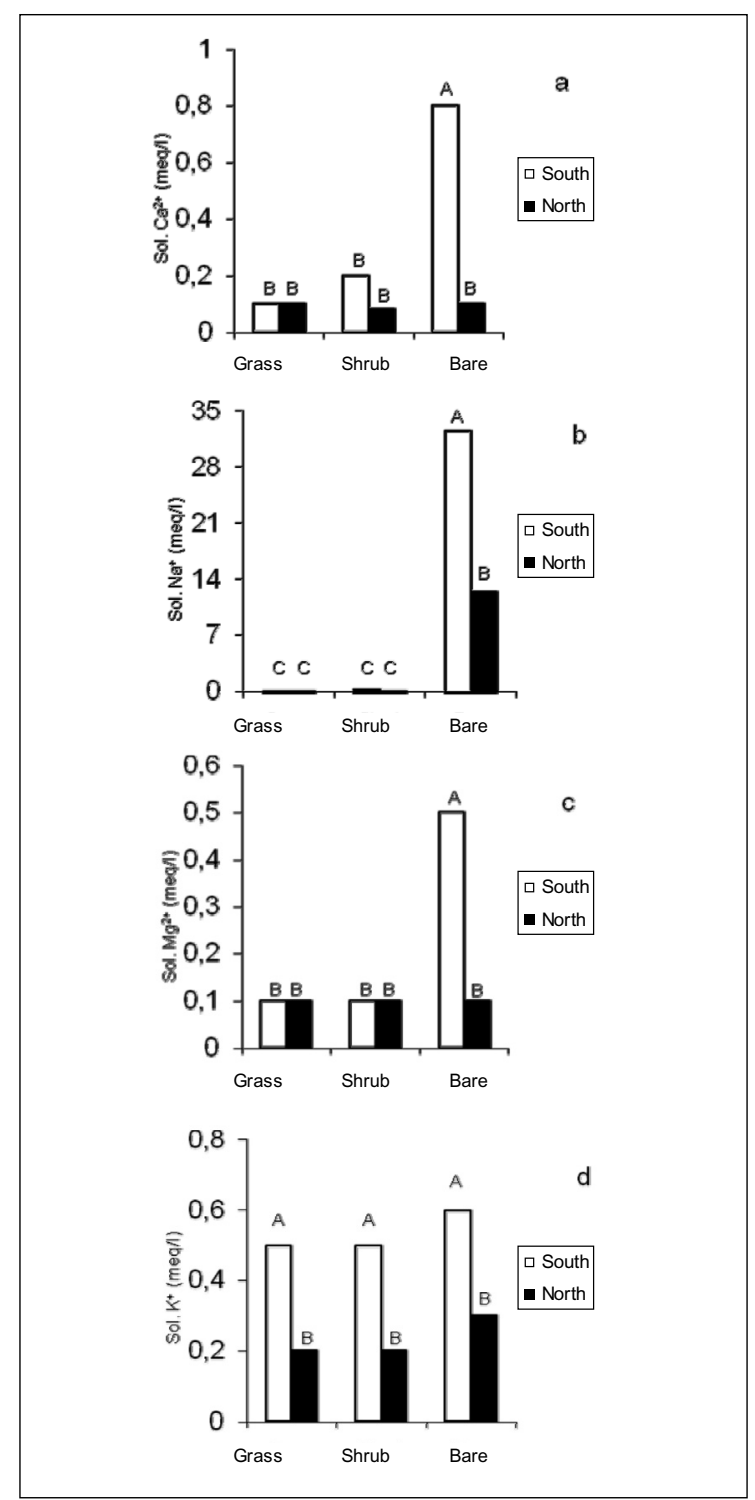

Figure 4. Soluble ions in soil water (meq/l): $\mathrm{a}=\mathrm{Ca}^{2+} ; \mathrm{b}=$ $\mathrm{Na}^{+} ; \mathrm{c}=\mathrm{Mg}^{2+} ; \mathrm{d}=\mathrm{K}^{+}$. Different letters show significantly different values for $\mathrm{P} \leq 0,01$.

On the south-facing slope the picture is further complicated by the different topography of areas with different soil cover, since grassland corresponds to less steep locations in this aspect.

Plant roots (Tab. 1) were not found in bare soil and RLD was highest in grassland sites, and in the north-facing slope for all types of vegetation. Root density was highly variable within sites, as shown by the standard deviations in the table, corresponding to coefficients of variation 


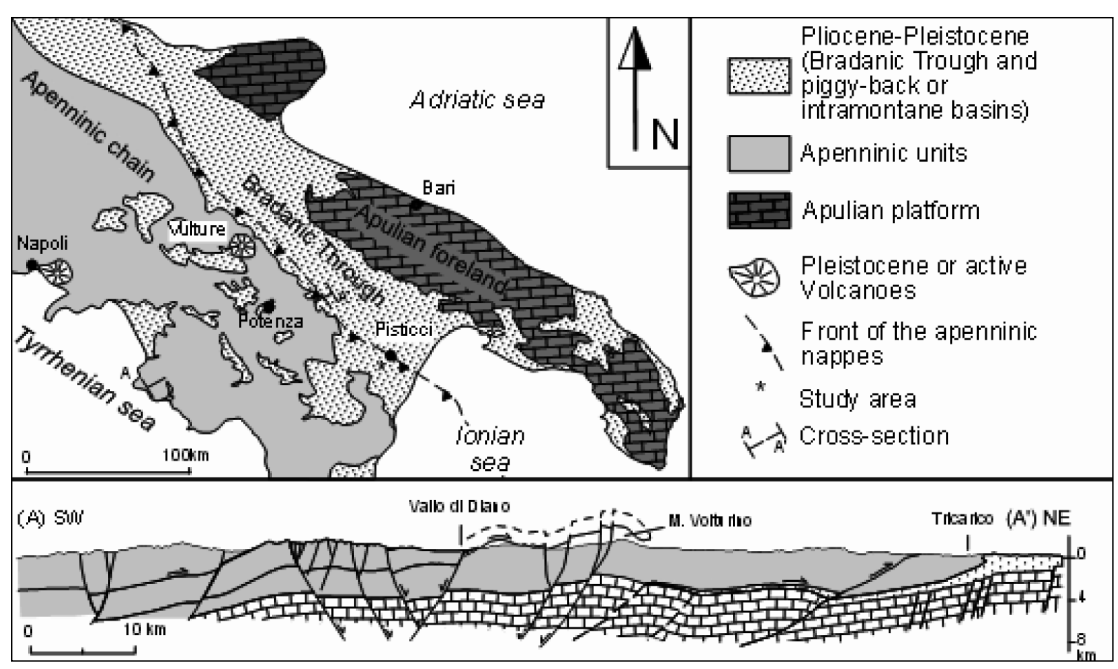

Figure 5. Map of the study area and structural scheme of the southern Apennines. Redrawn from Piccarreta et al., 2006. ranging from $14 \%$ in $\mathrm{GN}$ to around $40 \%$ in SS. A high variability in root data is common, especially when no structured component is identifiable (Amato and Ritchie, 2002), and the higher variability in shrubland, especially on south-facing slopes, is linked to the sparse soil cover and the architecture of shrubs compared to grasses.

Aggregate stability (Fig. 6), was the lowest in bare areas, and the highest for herbaceous vegetation for all pre-treatments as for the south facing slope while, in the north facing slope stability was the highest in shrub areas. Benzene pretreatments enhance the effects of organic matter, showing large differences between treatments, whereas alcohol pre-treatments enhance the cohesive effects due to clay-to-clay bonds (Henin et al., 1973), showing no significant difference.

The general trend of our values is in agreement with findings of Philips (1998b), who reported that the water stability of aggregates is closely related to organic matter content and that above a threshold of $2 \%$ stability would be between 90 and 100\%. Nevertheless he also found that where ESP is higher than 10-12, stability is between 10 and $50 \%$. The high number of sites analysed in that study allowed the author to formulate the observation that a high organic matter content is associated with a low ESP. Our results confirm this association: data in figure 8 are arranged in a soil Organic Matter - ESP plane, where thresholds for soil dispersive conditions are drawn at $2 \%$ organic matter and $12 \%$ ESP, according to Phillips, 1998b (for a discussion see Piccarreta et al., 2006). All data from bare soil fall in the dispersive condition quadrant, whereas soil samples from vegetated sites fall in non-dispersive conditions due to high O.M., low ESP or both. Data show that low values of ESP and high values of organic matter are associated with the presence of plant cover, and to the type of vegetation, allowing to substantiate the hypothesis that the two conditions are related because both functionally dependent on plant-driven processes. The former is most likely due to the known mechanisms of residue and exudates deposition and evolution under plant cover, and the latter due to salt uptake by halophytes and the less stressed effect of plants on those components of the soil water cycle which affect the salt balance (Amato, 2004). Aggregate stability is also related with high organic matter content and low ESP, and associated with vegetation cover.

The values of aggregate stability reported by

Tab. 1. RLD (Root Length Density) ( $\mathrm{cm} \mathrm{cm}-3)$ recorded under different covers in the study area.

\begin{tabular}{|c|c|c|c|c|c|c|c|c|}
\hline \multirow[b]{2}{*}{ Cover } & \multicolumn{3}{|c|}{ Average } & \multicolumn{3}{|c|}{ C.V. } & \multicolumn{2}{|c|}{ STDDEV } \\
\hline & Grass & Shrub & Bare & Grass & Shrub & Bare & & \\
\hline South & 5,60 & 0,25 & 0 & 15,96 & 40,40 & 0 & 0,89 & 0,10 \\
\hline North & 7,20 & 1,40 & 0 & 14,18 & 28,43 & 0 & 1,02 & 0,40 \\
\hline
\end{tabular}




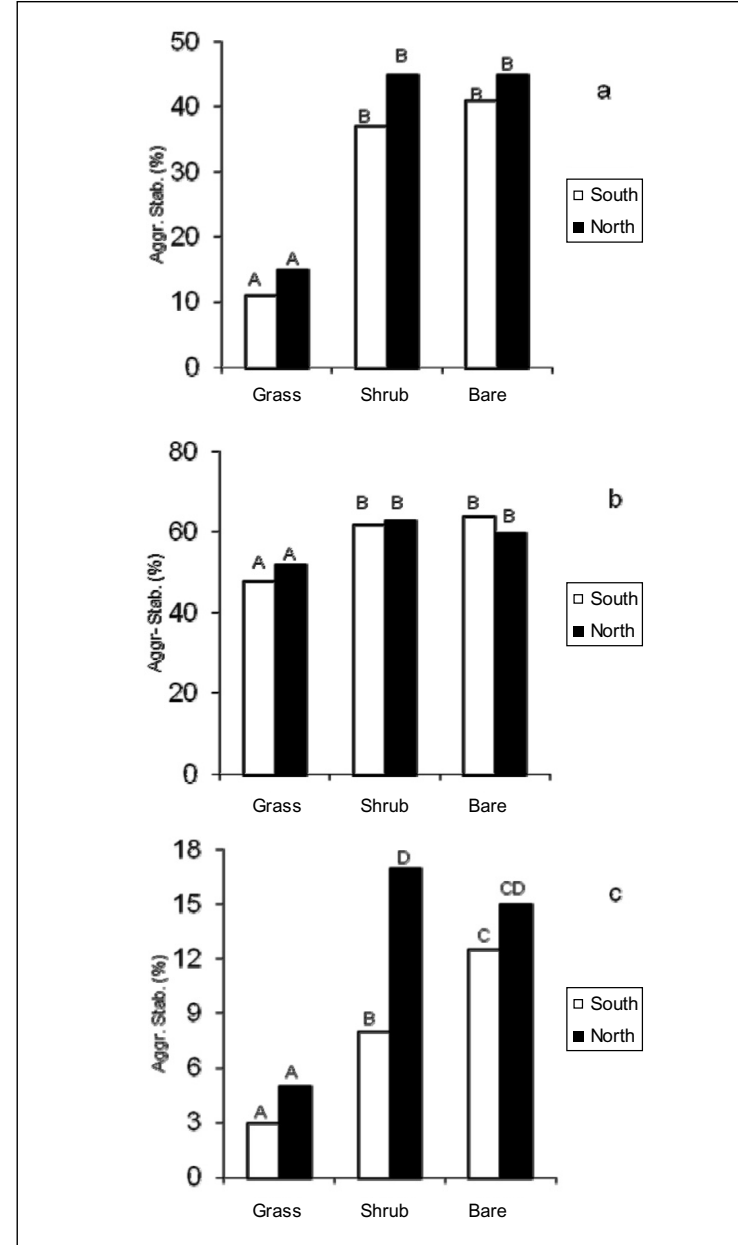

Figure 6. Aggregate stability in water (\% of stable aggregates): $\mathrm{a}=$ control; $\mathrm{b}=$ alcohol pre-treatment; $\mathrm{c}=$ benzene pre-treatment. Different letters show significantly different values for $\mathrm{P} \leq 0,01$.

Robinson and Phillips (2001) for bushland of the same area of our study was higher than those found in our study, maybe due to differences in time of sampling and aggregate size used, which are known to affect soil stability, as illustrated in the literature (e.g. Bryan, 2000; Patruno et al., 1992; Henin et al., 1973). Yearly oscillations of the stability index in Mediterranean climates are linked to seasonal rainfall and temperature patterns, affecting the strength of inter-aggregate bonds mainly through the physical-chemical action of water, microbial activity, and compressive effects of soil freezing and drying (Patruno et al., 1992). Our choice to sample in September was linked to the need to characterize conditions relevant for soil erosion, fol- lowing reports that most of the erosion in the area occurs with the early fall rainstorms (Clarke and Rendell, 2000). Furthermore, in this study, small aggregates (equivalent diameter $<2 \mathrm{~mm}$ ) were chosen for the measurements because they are less sensitive to micro-variations linked to very short-term conditions (Patruno et al., 1992).

In our study bush vegetation was represented by isolated individuals on the south-facing slopes, and our interpretation of the observation that their influence on soil properties was smaller than that of herbaceous communities is partly linked to the fact that their limited spatial extent reduces their influence on the soil processes linked to aggregate stability (evaporation and deposition of organic matter), whereas the continuity and larger spatial extent of herbaceous plant cover allows them to affect those processes more markedly.

Shrinkage curves (Fig. 7) showed differences between bare and vegetated areas for some parameters only. The values of the intercept for the residual contraction curve phase was not statistically different among treatments. This is in agreement with the interpretation of this parameter as being affected by texture more than by other factors (Cornelis, et al., 2006; Chertkov, 2003). In fact, it represents the intra-aggregates porosity, being roughly $27 \%$ of dry soil volume for all treatments in our study. The slope of this curve stage was around 0,5 for all curves. The 'normal' shrinkage phase of the curve did not significantly differ among treatments, its slope not being statistically different from 1 in all areas, corresponding to a unitary decrease of water content per unit decrease of specific volume.

The structural shrinkage stage was detected in bare soil samples only, with a higher slope in BS (Fig. 7a) than in BN (Fig. 7d), and was missing in samples from vegetated sites with live roots. This phase corresponds to water replacement by air in inter-aggregate pores and therefore only occurs in soils that develop inter-aggregate porosity. This condition has been discussed in terms of presence of biological activity (Cornelis et al., 2006) in well-structured soils. While being a generally valid interpretation, our findings lead to question its validity for badland soils. In fact, in saline badland soils the presence of inter-aggregate pores is not due to aggregation dynamics linked to the formation of bio- 


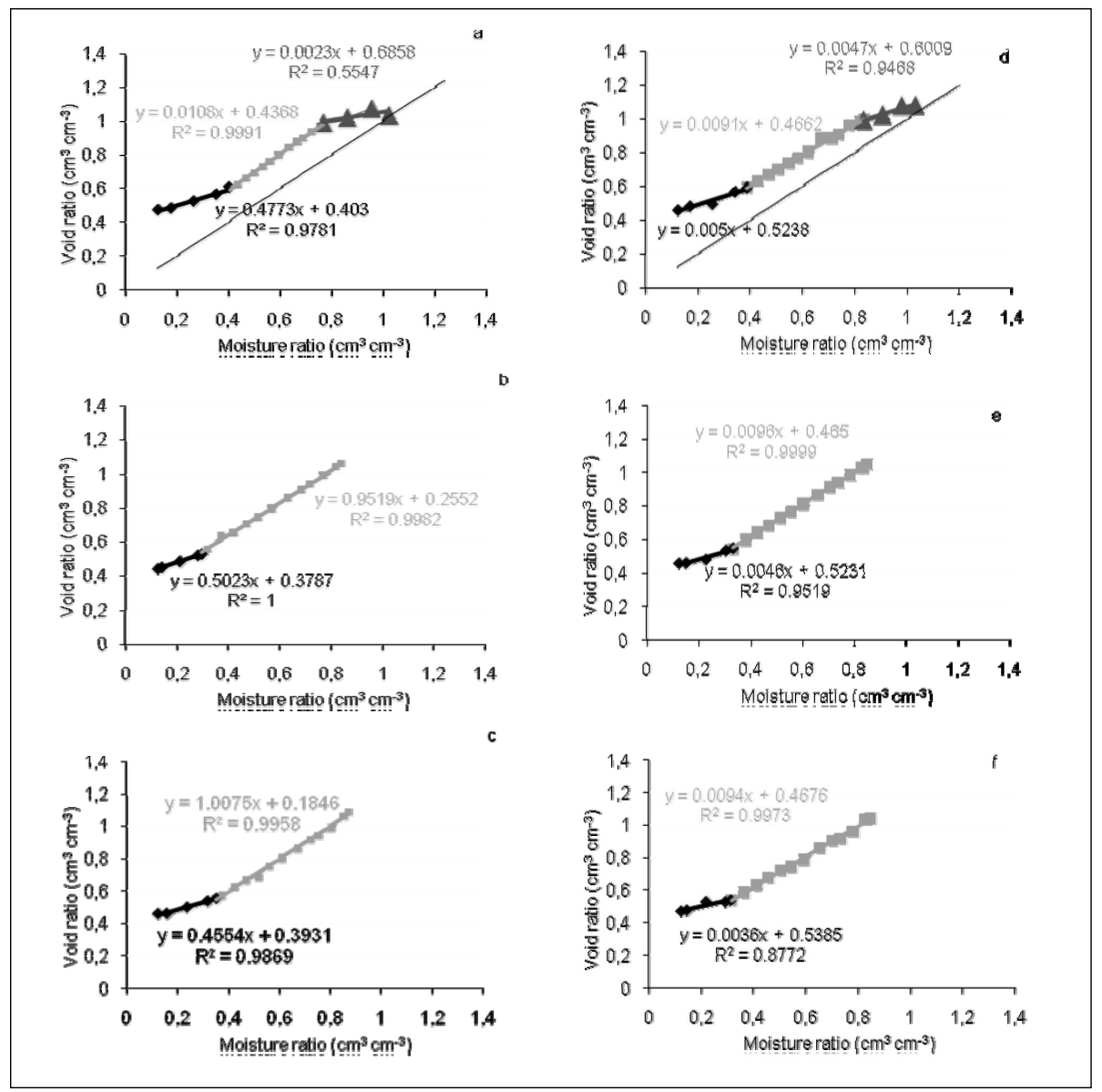

Figure 7. Shrinkage curves under different aspect and soil cover: $\mathrm{a}=$ $\mathrm{SB} ; \mathrm{b}=\mathrm{SS} ; \mathrm{c}=\mathrm{SG}, \mathrm{d}=$ $\mathrm{NB} ; \mathrm{e}=\mathrm{NS}$ and $\mathrm{f}=\mathrm{NG}$.

pores and their stabilization by organic matter, but to fragmentation dynamics creating a hierarchic network of cracks under desiccation, and therefore it is much more likely to be enhanced in the absence of biological activity. In vegetated areas the reduction of sodium concentration

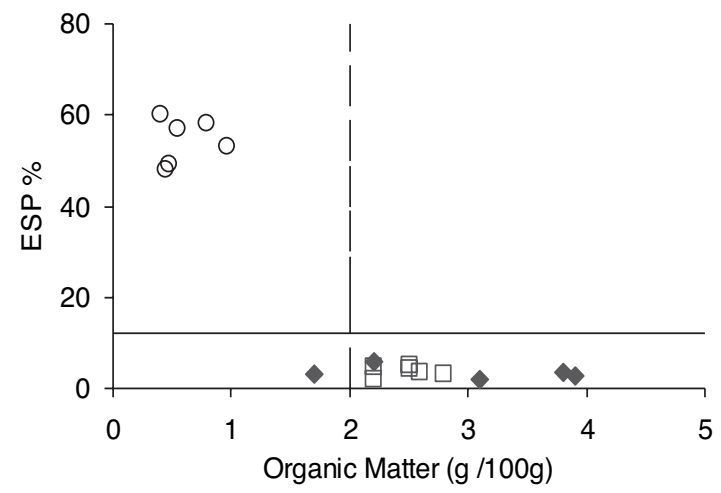

Figure 8. Relationship between ESP and O.M. Circles = south and north facing bare soils, squares = grass covered soils, and lozenges $=$ shrub covered soils. and the increase of organic matter explain a part of the reduced soil swelling, and in addition the presence of an active root network is likely to exert a bridling effect contrasting soil swelling under wetting and the formation of cracks upon drying. To support our finding, other studies on the effect of vegetation on soil cracking showed that the presence of vegetation is associated with reduced swell-shrink soil behaviour (Mitchell and van Genuchten, 1992; Fox, 1964) and plants with dense root networks and high mechanical strength of roots reduce soil cracking compared to bare soils (Di Tommaso et al., 2007). Our shrinkage curves showed that, during saturation, aggregates from vegetated areas didn't swell to the same extent as those taken from bare soil: aggregates from bare soils reached a moisture value greater than $45 \%$ in weight and a $0,80 \mathrm{~cm}^{3} \mathrm{~g}^{-1}$ specific volume, while those from vegetated areas reached a moisture value smaller than $35 \%$ except the ag- 
gregates from SS which attained a water content of $41 \%$. This confirms the lesser effect that the isolated plants have on soil characteristics, as already described for chemical properties.

\section{Conclusions}

The presence and type of vegetation in a badland area were associated with differences both in soil chemical characteristics and in indicators linked to soil stability like ESP, soil stability index and shrinkage curves. All indicators of soil sensitivity to erosion indicated that the highest stability was associated with shrubland in the north facing slope and grass cover in the south facing slopes, likely due to the lack of continuity in the south-slope shrub formations. The use of soil stability indicators linked to aggregate shaking in water can be integrated with additional information from shrinkage curves, describing the swelling behaviour of soils. The analysis of the single shrinkage phases highlighted the role of plant roots and soil chemical properties associated with plant cover in reducing overall soil swelling by affecting the structural swelling stage. An important finding of the analysis made with this technique is therefore that in saline badland soils swelling is complete and can be described with the theoretical reference curve only in bare soil areas, whereas curves obtained from vegetated areas (both shrub and grassland) do not conform to the three-stage model due to the lack of significant swelling and shrinkage in the structural phase, likely due to bridling by the root network and lower sodium content. This also leads to questioning the validity of the current interpretation of the structural shrinkage phase as an indicator of biological activity in badland environments, where inter-aggregate porosity is linked to fragmentation dynamics.

\section{References}

Alakukku L. 1996. Persistence of soil compaction due to high axle load traffic. I. short-term effects on the properties of clay and organic soils. Soil Till. Res., 37:211-222.

Amato M. 2004. Le relazioni fra piante ed acqua del terreno. In: Amato M., Migliozzi A., Mazzoleni S. Il sistema suolo-vegetazione. Liguori Editore, Napoli, 137-150.
Amato M., Ritchie J.T. 2002. Spatial distribution of roots and water uptake of Maize (Zea mays L.) as affected by soil structure. Crop Science, 42:773-780.

Amato M., Pardo A. 1994. Root length and biomass losses during sample preparation with different mesh sizes. Plant and Soil, 161:299-303.

Arvidsson J. 2001. Subsoil compaction caused by sugar beet harvesters in southern Sweden. I. soil physical properties and crop yield in six field experiments. Soil Till. Res., 60:67-78.

Arvidsson J., Hakansson I. 1996. Do effects of soil compaction persist after ploughing? Results from 21 longterm field experiments in Sweden. Soil Till. Res., 39:175-197.

Black G.R., Hartge K.H. 1986. Bulk Density. In: Klute A. (ed.): Methods of soil analysis. Part $1,2^{\text {nd }}$ edition. Agronomy publications, 9:363-375.

Blackwell P.S., Green T.W., Mason W.K. 1990. Responses of biopore channels from roots to compression by vertical stresses. Soil Sci. Soc. Am. J., 54:1088-1091.

Boivin P., Schaffer B., Temgua E., Gratier M., Steinman G. 2006. Assessment of soil compaction using soil shrinkage modelling: Experimental data and perspectives. Soil and Tillage Research., 88:65-79.

Bouma J. 2002. Land quality indicators of sustainable land management across scales. Agriculture, Ecosystems and Environment, 88:129-136.

Braudeau E., Mohtar R.H., Chainian N. 2004. Estimating soil shrinkage parameters. Developments in Soil Science, 30:225-240.

Braudeau E., Costantini J.M., Bellier G., Colleuille H. 1999. New device and method for soil shrinkage curve measurement and characterization. Soil Sci. Soc. Am. J., 63:525-535.

Bronswijk J.J.B. 1991. Relation between vertical soil movement and water-content changes in cracking clays. Soil Sci. Soc. Am. J., 55:1220-1226.

Bruand A., Prost R. 1987. Effect of water content on the fabric of a soil material: an experimental approach. J. Soil Sci., 38:461-472.

Brullo S., De Marco G., Signorello P. 1990. Studio fitosociologico delle praterie a Lygeum spartum dell'Italia meridionale. Boll. Acc. Gioenia Sci. Nat., 23(336):561-579.

Bryan R.B. 2000. Soil erodibility and processes of water erosion on hillslope. Geomorphology, 32:385-415.

Bullock P., Newman A.C.D., Thomasson A.J. 1985. Porosity aspects of the regeneration of soil structure after compaction. Soil Till. Res., 5:325-341.

Cavazza L., Linsalata D. 1969. Misura della stabilità di struttura del terreno. Riv. di Agron., 3:50.

Chertkov V.Y. 2003. Modelling the shrinkage curve of soil clay pastes. Geoderma, 112:71-95.

Chertkov V.Y. 2007. The reference shrinkage curve of clay soil. Theoretical and Applied Fracture Mechanics, 48:50-67. 
Clarke M., Rendell H.M. 2000. The impact of the farming practice of remodelling hillslope topography on badland morphology and soil erosion processes. Catena, 40:229-250.

Clarke M.L., Rendell H. 2005. Process-form relationships in Southern Italian badlands: erosion rates and implications for landform evolution. Earth Surf. Processes Landf., 31(1):15-29.

Cornelis W.M., Corluy J., Medina H., Diaz J., Hartmann R., Van Meirvenne M., Ruiz M.E. 2006. Measuring and modelling the soil shrinkage characteristic curve. Geoderma, 137:179-191.

Del Prete M., Bentivenga M., Amato M., Basso F., Tacconi P. 1997. Badland erosion processes and their inteactions with vegetation: a case study from Pisticci, Basilicata, Southern Italy. Geogr. Fis. Dinam. Quat., 20:147-155.

Di Tommaso T., Lovelli S., Perniola M. 2007. Influenza delle radici sulla crepacciatura nei terreni rigonfiabili. Atti XXXVII Convegno Nazionale della SIA "Il contributo della ricerca agronomica all'innovazione dei sistemi colturali mediterranei", 13-14 settembre, Catania, Italia.

Farifteh J., Soeters R. 1999. Factors underlying piping in the Basilicata region, southern Italy. Geomorphology, 26:239-251.

Fox W.E. 1964. Cracking characteristics and field capacity in a swelling soil. Soil Sci., 98:413.

Greenway D.R. 1987. Vegetation and Slope stability. In: Anderson M.G., Richards K.S. (eds.): Slope stability, 187-230. John Wiley and sons, New York.

Grieve I.C. 1979. Soil aggregate stability tests for geomorphologists. In: British Geomorphological Research Group Technical Bulletin 25. Geoabstracts, Norwich.

Groenevelt P.H., Grant C.D. 2001. Re-evaluation of the structural properties of some British swelling soils. Eur. J. Soil Res., 52:469-477.

Groenevelt P.H., Grant C.D. 2004. Analysis of soil shrinkage data. Soil and Tillage Research, 79:71-77.

Gupta S.C., Sharma P.P., De Franchi S.A. 1989. Compaction effects on soil structure. Adv. Agronomy, 42:311-338.

Haines W.B. 1923. The volume changes associated with variations of water content in the soil. J. Agric. Sci. Cambridge, 13:293-310.

Henin S., Gras R., Monnier G. 1973. Il profilo colturale. Edagricole, Bologna.

Hillel D. 1971. The state of water in the soil. In: Soil and Water: Physical Principles and Processes. Academic Press, New York, 49-77.

Horn R., Werner D., Baumgartl T., Winterot C. 1994. Effects of wheeling on stress distribution and changes in the macro-and microstructure of a cambic phaeozem derived from loess. Zeitschrift für Pflanzenernährung und Bodenkunde. J. Plant Nutr. Soil Sci., 157:433-440.
Horn R., Domzal H., Slowinska-Jurkiewicz A., van Ouwerkerk C. 1995. Soil compaction processes and their effects on the structure of arable soils and the environment. Soil Till. Res., 35:23-36.

Johannesson K.H., Lyons W.B. 2000. Rare earth elements in groundwater. In: Cook P., Herczeg A. (eds.): Environmental Tracers in Subsurface Hydrology, 485-492. Kluwer, Dordrecht, The Neaderlands.

Kirby J.M. 1991. The influence of soil deformation on the permeability to air. J. Soil Sci., 42:227-235.

Kremer J., Wolf B., Matthies D. 2002. Structural deformation of artificial macro-pores under varying load and soil moisture. Zeitschrift für Pflanzenernährung und Bodenkunde. J. Plant Nutr. Soil Sci., 165:627-633.

Logsdon S.D, Allmaras R.R., Nelson W.W., Voorhees W.B. 1992. Persistence of subsoil compaction from heavy axle loads. Soil Till. Res., 23:95-110.

McGarry D., Daniells I.G. 1987. Shrinkage curve indices to quantify cultivation effects on soil structure of a Vertisol. Soil Sci. Soc. Am. J., 51:1575-1580.

McGarry D., Malafant K.W.J. 1987. The analysis of volume change in unconfined units of soil. Soil Sci. Soc. Am. Proc., 6:113-116.

Mitchell A.R. 1992. Shrinkage terminology: escape from "normalcy". Soil Sci. Soc. Am. J., 56:993-994.

Mitchell A.R., Van Genuchten M.T. 1992. Shrinkage of bare and cultivated soils. Soil Sci. Soc. Am. J., 56:10361042.

Newman E.I. 1966. A method of estimating root length in a sample. Journal of Applied Ecology, 3:139-145.

Patruno A., Cavazza L., Vicari A. 1992. variazioni temporali della stabilità di struttura in relazione a decorso meteorico, coltura e modalità di lavorazione. Riv. Ing. Agr., 1:16-26.

Phillips C.P. 1998a. The badlands of Italy: a vanishing landscape? Applied Geography, 18:243-257.

Phillips C.P. 1998b. Reclaiming the erosion susceptible landscape of the Italian badlands for arable cultivation, Land Degradation \& Development, 9:331-346.

Piccarreta M., Faulkner H., Bentivenga M., Capolongo D. 2006. The influence of physico-chemical material properties on erosion processes in the badlands of Basilicata, Southern Italy. Geomorphology, 81:235251.

Rendell H.M. 1982. Clay hillslope erosion rates in the Basento Valley, S. Italy. Geografiska Annaler, 64A:141-147.

Rendell H.M. 1986. Soil erosion and land degradation in southern Italy. In: Fantechi R., Margaris N.S. (eds.): Desertification in Europe, 184-193. Commission of the European Communities, Brussels.

Richards G., Cousin I., Sillon J.F., Bruand A., Guerif J. 2001. Effect of soil compaction on the porosity of a silty soil: influence on unsaturated hydraulic properties. Eur. J. Soil Sci., 28:509-518.

Ritchie J.T. 1972. Model for predicting evaporation from 
a row crop with incomplete cover. Water Resources Res., 8:1204-1213.

Robinson D.A., Phillips C.P. 2001. Crust development in relation to vegetation and agricultural on erosion susceptible, dispersive clay soil from central and southern Italy. Soil Tillage Res., 60:1-9.

Skaggs T.H., van Genuchten M.T., Shouse P.J., Poss J.A. 2006. Macroscopic approach to root water uptake as a function of water and salinity stress. Agric. Water Manag., 86:140-149.
Stirk G.B. 1954. Some aspects of soil shrinkage and the effect of cracking upon water entry into the soil . Aust. J. Agric. Res., 5:279-290.

Wiermann C., Werner D., Horn R., Rostek J., Werner B. 2000. Stress/strain process in a structured unsaturated silty loam Luvisol under different tillage treatment in Germany. Soil Till. Res., 53:117-128.

Worrall F., Pearson D.G. 2001. Water-rock interactions in an acidic mine discharge as indicated by rare element patterns. Geochim. Cosmochim. Acta, 65:30273040. 